\title{
To study the quality issues of garment export house of Noida (With special reference to AMS fashions export house)
}

\section{ARUSHI JABEEN AND NAZNEEN JABEEN}

Received: 10.09.2017; Revised: 24.10.2017; Accepted: 09.11.2017

See end of the paper for authors' affiliations NAZNEEN JABEEN

Department of Home Science, M.L.\& J N.K.Girls College, SAHARANPUR (UP).INDIA
ABSTRACT : Garments are needed by every person according to his/her requirements and the condition where they live and work. Although most of the people now wear readymade garments but still individual tailors are also used by large number of people in the society. There are many organizations, societies and departments where ready-made garment are used. For a supply in large qualities and for fashion and design garment industries came into existence. However each and every industry does not produce the same type of garment. Their quality also resumes different but there is a requirement of cheapness and durability of garment. There are different types of jobs in garment making where different process are involved in order to get produce an acceptable material at low product cost. Lasting of facilities in these departments may affect the quality, cost and acceptability.

KEY WORDS: Garments, Readymade garment, Quality, Quality control and cost

- HOW TO CITE THIS PAPER : Jabeen, Arushi and Jabeen, Nazneen (2017). To study the quality issues of garment export house of Noida (With special reference to AMS fashions export house). Asian J. Home Sci., 12 (2) : 552-557, DOI: 10.15740/HAS/AJHS/12.2/552-557. 